\title{
Theological education in Africa: \\ Messages from the fringes
}

NGTT DEEL 55, NO 1, 2014

\section{Hendriks, H Jurgens}

Stellenbosch University ${ }^{1}$

\begin{abstract}
The article asserts that the quest for power is one of the debilitating cultural impediments that keep theological education caught in an outdated paradigm. It uses case studies to illustrate the hypothesis as well as the journey to escape the stranglehold of the colonial heritage. Philippians 2:1-18 posits the normative theological principle of kenosis that should guide us in passing through the needle of an old paradigm. An experience in Kampala and research from the Anglican Church in Kenya illustrate the problem while case studies from Angola, Malawi and South Africa illustrate the paradigm shift from an institutional to a missional paradigm in theological education.
\end{abstract}

1 Jurgens Hendriks is an emeritus professor in Practical Theology at Stellenbosch University and Executive Director of the Network for African Congregational Theology (NetACT). Email address: hih@sun.ac.za 


\section{INTRODUCTION}

The relationship between leadership and power may be the biggest problem that we face in our continent. Does theological education provide the right kind of training for church leaders so that they can illustrate a Christian alternative? We have come to the end of the Christendom era with its strong institutional focus (Walls 2002). It is a relief that the missional identity of the church has been rediscovered. ${ }^{2}$ The paradigm shift from an institutionally centred church to that of a missional one has profound ontological and epistemological roots. This is important to understand, but is not the direct focus of this article. ${ }^{3}$ In missional theology, one of the most important lessons to learn is listening to the fringes, to the voices of "the other." ${ }^{\text {" One }}$ of the advantages of the networking of theological institutions in Africa is the fact that it opens fresh perspectives on issues (e.g. theological education), which have become bogged down in tradition and institutional hierarchies. This article tells the stories of colleagues and institutions in our continent.

As a practical theologian, I believe that theology is a continuing hermeneutical concern that discerns how the Word should be proclaimed in word and deed in the world (Hendriks 2004:19). This discernment is not simply an academic rational activity, but a journey of faith like that of Abraham. We are in a liminal space as regards theological education and we need to journey together to understand what the missional implications of this paradigm shift entail ${ }^{5}$. Thus, the article will focus on the Word as well as on observations made while journeying in Africa.

2 Missional church literature is flooding the market. My journey started with Bosch (1991), Newbigin (1989) and Guder (ed. 1998).

3 David Bosch (1991) and Meylahn (2012) will be of assistance in this regard.

4 Walls (2002: 32) illustrates from history how mayor missiological breakthroughs took place when Christians outside of the inner circle of the institutional hierarchy were given the freedom to initiate work guided by the Word and the Spirit.

5 The writer concurs with the Cape Town Commitment (2012:52) of the Lausanne movement: "Those of us who lead churches and mission agencies need to acknowledge that theological education is intrinsically missional. Those of us who provide theological education need to ensure that it is intentionally missional, since its place within the academy is not an end in itself, but to serve the mission of the Church in the world." 


\section{KAMPALA'S SILENCE}

I was a plenary speaker at a TEA conference ${ }^{6}$ in Kampala in August 2013. The paper was titled Contextualizing Theological Education in Africa by doing theology in a missional hermeneutic (Hendriks 2013a:818-831). The animated audience of 350 people ranged from untrained pastors (from the African Initiated Churches) with no formal training, to vice-chancellors of Christian universities. During the presentation, I asked the audience "What are the characteristics of true Christian leadership?" The reaction was immediate and enthusiastic and I acknowledged all the answers. However, I continually repeated that I missed what, to my mind, was the most important answer. After a while, the group became silent and despondent. Upon my explanation that leadership's most important characteristic is the giving away of power, their reaction was apparent disbelief, a dumbfounded silence. After seconds of silence, I asked whether they knew of an African president who gave his power away after just one term in office. The lights went on! Upon my questions, "What was the case of most African presidents?" there was laughter! And, "Who was the most respected African president?" "Mandela!" rang out.

These questions initiated myriads of discussions. The point was that the inability to share and give power away is one of the scourges of African leadership and distinctly does not follow Christ's example. The patriarchal family, the tribal system, the leadership style of African leaders were mentioned and discussed. Authoritative leadership that keeps power centralised also has its parallel in the church. This, I think, is something we need to address in our journeying in this continent and especially in theological education. Let's use this cue as a hermeneutical tool to address the question on how to train leaders.

If theology is about listening to the world and the Word, we should actively engage in listening to the Word, especially in liminal phases, where we try to find a way forward. ${ }^{7}$ The question put to the Kampala audience had its origin in the congregation where I serve as an elder. The congregation had experienced a difficult leadership transition and decided to dwell in the Word, ${ }^{8}$ i.e. Philippians 2:1-18, at all the church

6 TEA is an acronym for Theological Education in Africa. The Christian Reformed World Missions Eastern and Southern Africa Ministries held its third TEA conference in Kampala, Uganda, in August 2013.

7 Keifert, in Keifert (ed.) 2009:27-47, uses the same approach when addressing the challenge. His chapter "The Bible and theological education: A report and reflections on a journey" echoes the same approach as this article.

8 Dwelling in the word is a discernment exercise in which the Bible plays the key role (Ellison 2009). 
board's meetings. ${ }^{9}$ This we did for two years. The Word is slowly transforming us; thus, the congregation's identity is also being transformed. We had to unlearn a CEO leadership style, ${ }^{10}$ and are currently in a process of discovering how to give power away. The challenge to understand the role of leadership in empowering a congregation for missional, Kingdom service, confronts us. In this article, dwelling on Phil 2:1-11 is also a crucial part of the journey; it describes the theology of giving away power! Read and reflect on this passage.

\section{THE MESSAGE ABOUT DOWNWARD MOBILITY}

\section{Philippians 2:1-18: He took on the status of a slave}

1-4 If you've gotten anything at all out of following Christ, if his love has made any difference in your life, if being in a community of the Spirit means anything to you, if you have a heart, if you care then do me a favour: Agree with each other, love each other, be deep-spirited friends. Don't push your way to the front; don't sweet-talk your way to the top.

Put yourself aside, and help others get ahead.

Don't be obsessed with getting your own advantage.

Forget yourselves long enough to lend a helping hand.

5-8 Think of yourselves the way Christ Jesus thought of himself.

He had equal status with God but didn't think so much of himself that he had to cling to the advantages of that status no matter what. Not at all. When the time came, he set aside the privileges of deity and took on the status of a slave, became human!

9 The passage from the translation in The Message is used because it is a contextualized translation. I consulted Wright (1991:56-98) and Gorman (2009:9-39) on this passage but refrained from indulging in the exegetical detail. The broad and basic significance for our topic is, however, clear. Gorman (:13) writes: “... I would suggest that Phil 2:611 is truly Paul's master story." Similarly the passage forms a crucial chapter in Wright's (56-98) book.

10 CEO or Chief Executive Officer refers to an executive officer or leader with more or less absolute power that usually rules his/her organization in an authoritarian way. 
Having become human, he stayed human.

It was an incredibly humbling process.

He didn’t claim special privileges.

Instead, he lived a selfless, obedient life and then died a selfless, obedient deathand the worst kind of death at that-a crucifixion.

9-11 Because of that obedience, God lifted him high and honoured him far beyond anyone or anything, ever, so that all created beings in heaven and on earth-even those long ago dead and buried-will bow in worship before this Jesus Christ, and call out in praise that he is the Master of all, to the glorious honour of God the Father. ${ }^{11}$

\section{KENOSIS AND THEOLOGICAL EDUCATION}

Philippians 2 is about the paradox of power. Paul is in prison in Rome. Epaphroditus visits him (2:25). Paul writes this letter to thank the Philippians for their generosity, but also to encourage them and advise them about the meaning of following Christ in an awfully dangerous and broken world. The context is described by words such as opposition, suffering, struggle, death and dying, and a corrupt, squalid and polluted society; but also words like courage, victory, obedience, trust, joy, etcetera. This is applicable to many places on our continent where we too must train successors to Timothy and the Philippian congregation. What are the theological parameters that should shape this training?

- First and foremost, it is about following Christ. Philippians 2:1: "If you've gotten anything at all out of following Christ ... "What does "following Christ" imply in training Christian leaders?

- Philippians 2:1-4 says that this implies that the love, community and compassion of the Trinity should become visible in harmony, love and unity amongst Christ's followers. It implies being utterly unselfish, crucifying individualism's ego-alpha male culture. It is about "downward mobility" (Gorman 2009:16).

- Jesus Christ exemplifies this (2:6-8). Followers of Christ are "in Christ" if a three-step journey is embarked upon: 1) Christ had equal status before God, but 2) He relinquished this and became human. 3) He lived a selfless, obedient life and died a selfless, obedient death - crucified.

11 Peterson, E.H., 2002, The Message: The Bible in contemporary language, Php 2:1-18, NavPress, Colorado Springs, Colo. 
The key word here is kenosis, which means emptying in Philippians 2:6, He "emptied himself." He unselfishly surrendered his pre-existent, divine mode of being (Brown 1975:1:547) and gave himself to a broken world. Healing comes through brokenness: his crucifixion led to his resurrection.

- This is about the paradoxical mystery of giving away power and having power in a new and stronger, but counter-intuitive, way. The translation in The Message (2:13) senses this as follows: "Be energetic in your life of salvation, reverent and sensitive before God. That energy is God's energy, energy deep within you ...."

- The passage is about the crossing of sometimes-intractable boundaries. Kenosis is about emptying, about moving purposefully from one way of being to another; serving and self-sacrifice. God becoming human and, being human, he took the disciples to people and places where they had never been before. Some lectures were in the temple, but most were not. He took them where people were suffering, where human dignity was wasted, trampled upon. There he healed, fed and taught.

- This passage reveals the essence of a missional theology, of the missio Dei. Gorman (2009:38) summarizes it:

The community that bears witness to this divine mission (Phil 2:12-18) does so through participation, by means of Spirit-enabled theoformity, in the reality of the life of the kenotic triune God that is described in Philippians 2:1-4 and revealed in Paul's master story of the incarnate, crucified, and exalted Messiah (Phil 2:6-11) who effects the eschatological mission for God the Father.

Philippians 2 provides a glimpse of God's counterintuitive kenotic and cruciform identity that should be an integral part of theological education in order to form its dream and goal. Does this narrative of a vulnerable God inform and structure a missional theological education?

Probe the current practice by asking:

- If downward mobility is what it takes to follow Christ, if unselfish service and giving form is the essence of theosis, ${ }^{12}$ we should ask how it could be embodied in theological education.

12 Theosis refers to escaping from this world's corruption and temptation in order to become participants or partakers in the divine nature. Classic text: 2 Pet 1:4 (Gorman 2009:5). 
- Are the structures and organization, as well as the practice of theological educational institutions, predominantly institutional (law) or missional (and kenotic) by nature (Wright 1991)?

- According to what parameters is the evaluation of theological education done?

- How do we evaluate theological students and how do we reward "good students?" Who receives bursaries? Do the principles of Philippians 2 play any role?

- Do we cross boundaries in theological education? Do we go out to where it hurts? How do we choose our professors and how do they teach? Do they, like Christ, set an example in crossing boundaries? Are they present (physically) with their students where people are in pain?

- Are discipleship principles - the way that the Christ taught his disciples still applicable in any practical way? Describe the typical setup in theological schools and the relationship and interaction between the staff and students. Discuss this. Are these two scenarios not two systemically different realities? How do we handle the differences?

At the end of a 500 year era (Tickle 2008) and confronted with an emerging post-Christendom Christianity (Tickle 2012), theological education, in a sense, is embarrassed. Transformation processes are problematic. An emerging future challenges us to move from ego-systems to eco-systems (Scharmer \& Kaufer 2013). It involves the courage to stop downloading old patterns and systems and to suspend your inner voices of judgement, cynicism and fear. It requires an open mind, an open heart and an open will, gaining a sense from the world and Spirit by being present in the now of new opportunities. We need places and practices of quietude and presence, simply dwelling in the Word and in the world, letting the new come to us and, once we sense and experience it, embody and act upon it (Scharmer 2009:3847). This is about the release of the old forms of power and sense of security that the old paradigm systems offer. Many of these have collapsed, as evidenced in Europe and elsewhere in the global North (Jenkins 2002).

\section{THE ANGOLAN CURRICULUM}

Andrew Walls (2002:32), the superb observer of the missionary process in Christian history, especially in Africa, made this observation:

There is a significant feature of each of these demographic and cultural shifts of the Christian centre of gravity. In each case a threatened eclipse of Christianity was averted by its cross-cultural diffusion. Crossing cultural 
boundaries has been the lifeblood of historic Christianity. It is noteworthy that most of the energy for the frontier crossing has come from the periphery rather than from the centre. The book of Acts suggests that it was not the apostles who were responsible for the breakthrough of Antioch, whereby Greek-speaking pagans heard of the Jewish messiah as the Lord Jesus, but quite unknown Jewish believers from Cyprus and Greece (Acts 11:19-20).

A testimony from Angola on the "energy from the periphery" may be of assistance in our quest for rediscovering a way to teach theology in Africa. The following quote is from a brochure called "Kinkuni" of the Igreja Evangelica Reformada de Angola (IERA, i.e. the Reformed Church of Angola).

\section{Kinkuni Skills Training Seminary}

Years ago the Reformed Church in Angola (IERA) had a beautiful seminary at Kinkuni, Uige province in Angola. It was twice destroyed during the 40year period of war and faction fighting.

In rebuilding it as an open seminary for churches in the region a specific philosophy of theological training and of being church is followed. The church strives to make a difference in society. Its ministers will be trained in more than just theology. The seminary is also more than simply an academic compound. When pastors are doing practical work in congregations Kinkuni will be used as a skills training centre for local communities.

From its inception the seminary trained men and women in practical skills ranging from carpentry, farming, plumbing, teaching and whatever skills were required. As such they will be able to sustain themselves and earn a living while being ministers. They will also be able to train others in the skills that they have mastered.

The church will participate in the building of the new seminary. It will be a skills-training exercise in which the whole church, presbytery by presbytery, will come to Kinkuni to provide the labour. At the same time they will be trained in construction methods and acquire the appropriate certificates of competency. The goal is to empower congregations to form "companies" that can successfully complete building projects in their home areas. As such unemployment and sustainability will be addressed.

Since 2004, the writer has been involved with IERA and theological training at Kinkuni in the Uige province of Angola. A team from South Africa helped in 
planning the new seminary, writing its business plan, etcetera, but we had to discard our way of thinking about building and operating a seminary. The Angolans revealed a complete new understanding of a pastor's role and ministry. Before their war of independence and the subsequent cold war and faction fighting, pastors were trained in theology and skills with which to serve their communities, thus earning a living through work and the Word. Paul must have been their example. Not much in this regard has been documented; it simply lives in the church's shared memory. When they were ready to begin the process of rebuilding the twice-destroyed seminary, the fringes remembered and provided solutions. The writer did some research on the IERA's Western-style seminary training that took place in Luanda as from 1978 to date. It's not working. The Luanda-trained pastors are reluctant to work in the rural areas where they cannot earn a living wage. In a sense, they can deal only with the typical institutional way of being church where a congregation pays them. However, during the 40 years of war when the institution had to go underground, the church grew from 84000 members to an estimated 250000 - largely without seminarytrained pastors.

South Africa is part of Africa and we need to ask ourselves: What is happening in our continent? And, as we take cognizance of the fringes, we need to discern what their stories teach us about theological education and being church.

However, when considering Philippians 2, we recognize some patterns. The Angolans instinctively insisted that their new seminary should be built as a skills-training centre to equip their ministers for service in communities where, after 40 years of war, unemployment and a lack of skills are endemic. Theological training was viewed as an inherent part of community development, as the Gospel holistically reflects Jesus' ministry and crossing of boundaries. Even more fundamental: learning from their Luanda-training period, they realized that pastors, who are trained to serve an institution and receive salaries there, are reluctant to serve in rural congregations. Therefore, they want their pastors to be trained as community servants who are able to empower their communities through work and the Word.

\section{THE ANGLICAN DILEMMA IN KENYA}

Whereas the Angolan development is about adjusting its theological training to address contextual realities, the research of the Anglican Church of Kenya may assist us as it illustrates a worst-case scenario. However, this is not without precedent in South Africa. ${ }^{13}$ Case studies are useful to illustrate tendencies and systems (Babbie \& Mouton 2010:280-283; De Vos et al. 2011:320-322).

13 This section has been adapted from Hendriks 2013b:1006-1007. 
In 2008, Rev Dickson N Kagema (2008:2) completed his PhD on Leadership training for mission in the Anglican Church of Kenya at UNISA. His research question was: "How best should the Anglican Church of Kenya (ACK) train leaders who can effectively meet the demands of the rapidly growing Kenyan society?" To evaluate leadership training in Kenya, he applied the four-self mission strategy advocated by the ACK's own 2004 strategic plan. The aim of the leadership training should be a self-sustaining, self-propagating, self-governing and self-theologising church (2008:4, 41-53).

This research provides a general overview of the ACK, the above-mentioned mission strategy, its history and the growth of this Church. In 2007, the ACK had 3.7 million members constituting $10.6 \%$ of the total Kenyan population of 35 million (3.4\% more members compared to the 1980 census market share) (Kagema 2008:5467) while 1555 ordained clergy served its 4996 congregations (1352 parishes). This translates into roughly 2400 members per clergyman. Of the clergy $83 \%$ had diplomas or certificates and less than three years' training. Only $17 \%$ had degrees. An empirical analysis was made of the theological colleges and their curricula. The views of Anglican leaders (bishops, clergy, lecturers at colleges, lay and youth leaders) pertaining to the colleges' leadership training and curricula triangulated the data. A pretty uniform picture emerged (:144-235). Kagema's conclusions confirm the emerging picture of the church in Africa (:70):

The ACK lacks enough shepherds and the possibility is that most of its flock is spiritually unfed. It is practically impossible for one pastor to effectively satisfy the needs of such a big group. The challenges of the $21^{\text {st }}$ century are immense and call for a pastor who is quite near to his/her sheep so that he/ she can understand them and their challenges fully and as such he/she is in a position of meeting their spiritual needs.

In attempting to solve the problem of an adequate number of clergy, dioceses grouped together and started their own colleges. The process, however, was saturated with tribalism and a search for power (Kagema 2008:195):

... some of the theological colleges were started out of the desire by some of the church leaders to have their own colleges where they would have direct influence and control. ... this self-interest coupled with 'tribalism' has continued to affect the training of church leaders in the ACK up to date, greatly affecting the provincialization process ...

When the four-self requirements were put to the test at these colleges, all failed, which the church leaders acknowledge. The curricula are not contextualized and relevant. The seminaries are understaffed and depend on foreign donors for survival. 
The qualifications of the lecturers are substandard, while half of the principals are expatriates (Kagema 2008:199).

Regarding curriculum issues, Kagema (2008:232) is outspoken:

The curriculum of any learning institution is very important as it determines the kind of products produced by that institution. If the curriculum is haphazardly done, the people produced by it are also haphazard and their work is haphazard ... The clergy produced by these colleges are "half baked" ... And as such cannot stand the challenges of the $21^{\text {st }}$ century... This has rendered the ACK not to be a self-theologizing Church, a mission principle that is very instrumental for any growing church. ... the curricula used in the ACK Provincial Colleges are uncontextualised and irrelevant. These curricula look more Western than African and as such fail to address the main issues affecting the Kenyan society today.

As with the PCN in Nigeria, ${ }^{14}$ Kagema (2008:41-42) bewails the tribalism and points out that the chaos, which befell the country after the December 2007 elections, was due to pent-up ethnic anger that simply erupted as the different factions within the ACK supported their kin.

Throughout Kagema's dissertation, a self-destructing cycle is evident; because of a lack of leadership the ACK's decisions to improve theological training were not implemented and the financial problems continued. Those drawn to study as clergy are mostly low-level candidates unable to find employment or opportunities for study elsewhere. This is self-defeating; people no longer respect their fellow African clergy, catechists and evangelists. Good lecturers are scarce, underpaid, and more often than not tempted to emigrate, which exacerbates the brain drain of Africans who leave for lucrative work abroad (2008:22-34,288). At all the colleges, theological training is offered in English (2008:281). However, theology remains foreign if not taught in the mother tongue. Kagema's (:308-311) dissertation is an emphatic call addressed to the African Christian intellectual leadership.

This ends the summary of Kagema's dissertation.

A critical correlation between this case study and Philippians 2:1-18 highlights the discrepancy between the scriptural guiding principles and the ACK's educational system. The ACK may be a worst-case scenario, but it is the reigning system of theological education in many denominations in Africa. Kagema's honest remarks

14 The remark refers to another case study that was taken from the doctoral dissertation of Onwunta (2006), which was recently published (Onwunta 2010). 
on tribalism and issues of power should warn us that these tendencies are interwoven into the system. Our basic presupposition is that the typical Western theological system of education is institutionally, not missionally, driven. Kagema's research in the ACK leaves no doubt about this.

However, the ACK is growing in numbers. Why? Allow Malawi to answer this question.

\section{ANSWERS FROM MALAWI}

The dissertation of Dr Davidson Chifungo (2013) of the Church of Central Africa Presbyterian (CCAP), Nkhoma Synod, is an example from the fringes (see Walls 2002:32 discussed above) that can shed some light on our quest. The CCAP Nkhoma Synod was one of the founding members of NetACT, a Network for African Congregational Theology, ${ }^{15}$ which was founded during 2000 and 2001 in Kenya and Zambia. Its mission statement reads:

NetACT is a network of theological institutions in Sub-Saharan Africa, created and directed by these institutions, to assist them in preparing leaders for missional congregations.

In NetACT's first publication, Studying Congregations in Africa (Hendriks 2004), the Network motivates its emphasis on congregations. ${ }^{16}$ Subsequently, many PhD studies ${ }^{17}$ have dealt with this challenge proving the relevance and importance of training that focuses on empowering congregations. Few made a stronger case for this stance than Chifungo. The conviction of these leaders is grounded in scriptural passages, such as Philippians 2:1-18, which is about "downward mobility" and the role of pastors to empower people for missional ministry.

The growth of the CCAP Nkhoma Synod (Chifungo 2013:48-53) tells an important part of the story. Missionary work began in 1889. In 1962, the CCAP Nkhoma Synod received its autonomy from the Dutch Reformed Church (DRC) in South

15 NetACT's website http://academic.sun.ac.za/tsv/netact.html has the full history of the network, is well documented and kept up to date. One of the chapters in Phiri et al. (2013) Handbook for Theological Education in Africa, tells the NetACT story (Hendriks 2013b:1001-1017).

16 For the same emphasis and arguments, but applied to the Northern American situation, Keifert's chapter on "The return to the congregation in Theological Education" (in Keifert, [ed.] 2009:13-26) is informative.

17 Some examples available on the web are Msangaambe (2011), Ruturo (2007) \& Munikwa (2011). 
Africa. There were 35 congregations with approximately 1000 prayer houses, 70000 communicant members and 20000 catechumen. At the October 2012 Synod, it was reported that the church had 158 congregations, more than 2500 prayer houses and in excess of 1.5 million members, but 32 congregations had no clergy. However, Chifungo's most important observation was that $90 \%$ of the preaching was done by untrained lay preachers. As in the case of the ACK (above), the growth of the church is directly linked to the preaching and presence of the elders/lay preachers. Chifungo (2013:3-4) deals with this phenomenon and the abstract of his PhD dissertation reads:

This dissertation aims at recording, evaluating and analysing sermons of the lay preachers in the Church of Central Africa Presbyterian Nkhoma Synod in Central Malawi. Basically, these preachers have an oral culture. This analysis reveals the inherent ability of the oral lay preachers to communicate effectively using their indigenous knowledge system and modes of communication, which are characteristic of an oral culture.

Secondly, the analysis also reveals some lack in these sermons in terms of biblical understanding. Therefore, the purpose of this dissertation is to develop a homiletical theory and praxis, which will regard the biblical text and the people's context - Word and world - as serious.

Finally, the research proves that, if the strategy of implementing a training process in the congregations for all lay preachers, in order to empower them to use both their traditional modes of communication and an understanding of the Bible, could be realised, the spirituality of the people would improve and Christianity would have a greater impact in the society.

Msangaambe's (2011) research indicates how more than preaching can, and should, be implemented to attain community development and how missional practices realize core traits of God's Kingdom. However, both Msangaambe and Chifungo highlight a central theological principal from Phil 2:1-11. The clergy should give power away by empowering lay leaders and the laity. They should act as disciples by crossing boundaries to where people live and work. The growth of the church in Africa is taking place where ordinary people, lay-Christians, Women's Guild members and youth choirs are witnessing (Msangaambe 2011:57). Their research has proved that goal that NetACT leaders had set in 2001 concerning the empowering of congregational leadership, was sound.

The CCAP Nkhoma Synod makes good use of their lay training centre at Chongoni (Chifungo 2013:52; Msangaambe 2011:52). One of the biggest challenges to these young academics, which graduated with doctoral degrees, is not to fall into the trap 
of the institutional church and its power hierarchies. They could, and should, play a crucial role in the transformation of theological education, as they are the people who have seen the light!

\section{A MISSIONAL SHIFT IN SOUTH AFRICA}

Fresh expressions of the missional movement are appearing everywhere and in all denominations (Church of England 2009) and are catching on in South Africa. ${ }^{18}$ The DRC accepted a resolution at its 2013 General Synod that being church means being missional. It describes the basic theological framework of a missional church in great detail (Algemene Sinode Raamwerkdokument 2013:199-215). The attributes of Phil 2:1-17 are quite clear in the Raamwerkdokument. The following quotation illustrates downward mobility and empowerment (:209):

Gewone lidmate is die operasionele basis vanwaar die missio Dei begin. Hulle beklee sonder twyfel die belangrikste amp. Die ouderlinge en diakens (en leraars) kan nooit op hulle eie gemeentes help om volledig en in alle omstandighede sout vir die aarde en suurdeeg vir die wêreld te wees nie. Die lidmate is die sout en suurdeeg. (Laity is the operation base of the missio Dei. Theirs is the most important ministry. Elders, deacons (and pastors) cannot substitute congregations in being salt of the earth and yeast of the world. Laity should be the salt and the yeast (my translation).

This document also addresses theological training (:212-213). The reports of the Curatoria of the different Theological Faculties echo the first Raamwerk (Framework) report and the theological argument that it pursues (Algemene Sinode: Algemene Kuratorium 263-277, specifically addressed on pp. 273-276). It states explicitly that the DRC's identity is missional (:273) and that this implies discipleship (:274). Point 3:10 expounds the implications for missional leadership in terms of theological training (:276):

Voornemende predikante moet deur hulle teologiese opleiding gevorm word om geloofsonderskeidend met die Skrif om te gaan sodat die boodskap op 'n wetenskaplike verantwoorde wyse met die konteks in verband gebring kan word. In 'n missionale hermeneutiek moet die nodige kennis en vaardighede ontwikkel word oor die aard van kultuurverandering, die vorming van netwerke, die dinamika en sinergie van spanwerk. Daar moet geleer word om vernuwend en kreatief met

18 Google "Fresh Expressions." Websites such as this tell the story: http://www. freshexpressions.org.uk/missionshapedministry/george13 Accessed Nov 1, 2013. 
die (beperkte) middele om te gaan. (Theological training should form prospective ministers in discernment skills using Scripture as well as scientifically applicable contextual data to inform their sermons. A missional hermeneutic should shape knowledge and skills to understand cultural transformation processes, formation of networks as well as the dynamics and synergy of teamwork. Even when means are scarce innovative and creative ways to deal with challenges should be part of theological training (My translation).

There is no doubt that this sets the stage for serious wrestling with theological education. The practical steps that the DRC Synod accepted to implement its decisions are positive. So, the journey has started ... ${ }^{19}$

\section{IT IS NO EASY JOURNEY, BECAUSE THE CAMELS ARE LOADED}

The realities of our continent - its numerous problems and deep pain - confront the church with many challenges. The church is experiencing unprecedented growth which, obviously, is a mile wide and an inch deep. Theological education is being challenged. Can we train pastors and empower the laity to be the proverbial salt and light to make a difference in society?

In concluding this article, I want to share from the work of Otto Scharmer and the Presencing Institute, ${ }^{20}$ which I found most valuable to help organizations in

19 Robert Schreiter (2011:11) called this shift at the Catholic Maryknoll centennial symposium the "third wave of mission" and defines it "Regarding mission and evangelization in a world impacted by globalization, it follows that the agents of mission will be mobile, flexible, and part time. Most will come from the ranks of the laity." My observation in Africa in protestant circles is that the growth and "mission" of the church is linked to the role of laity in congregational and other networks. They are the prime agents, more so than "mobile, flexible and part time" agents.

20 From: http://en.wikipedia.org/wiki/Otto Scharmer (Accessed Oct 9, 2013): "Dr. C. Otto Scharmer is a Senior Lecturer at the Massachusetts Institute of Technology (MIT) and the founding chair of the Presencing Institute. He chairs the MIT IDEAS program and helps groups of diverse stakeholders from business, government, and civil society to innovate at the level of the whole system ... He also is a Vice-Chair of the World Economic Forum's Global Agenda Council on New Leadership Models. Scharmer introduced the concept of "presencing" - learning from the emerging future - in his bestselling books ... that have been translated into 15 languages ... With his colleagues, he has used presencing to facilitate profound innovations and changes in health, education, sustainability, and business systems. His best known publications are:

2013. Leading from the Emerging Future: From Ego-System to Eco-System Economies, Berrett-Koehler, San Francisco. Co-authored with Katrin Kaufer. 
liminal spaces in dealing with profound transformation. He often quotes Albert Einstein who said, "We cannot solve problems with the same kind of thinking that created them" (Scharmer \& Kaufer 2013:11). This, of course, is what Thomas Kuhn (1970) explains in greater detail. When a paradigm changes, everything changes. I referred to the works of Tickle (2008) and Walls (2002) who both, in their own way, described the historical paradigms and the liminal phase in which we are today. Thus, in concluding this article, a word from Scharmer \& Kaufer (2013:22) will help us to be more realistic about the challenge that we face:

Pass through the eye of the needle. At the deepest point of each $U$ journey ${ }^{21}$ is a threshold. Crossing that threshold, passing through the eye of a needle, can feel like dying and being reborn. According to the Bible, "It is easier for a camel to go through the eye of a needle than for a rich man to enter the kingdom of God." The phrase "eye of a needle" refers to a gate in ancient Jerusalem: For a man to fit his camel through Jerusalem's gate, he had to remove all the bags from the camel's back. Likewise, if we want to go through the eye of the needle at the bottom of the $U$, we have to let go of everything and offload all the baggage that isn't essential. Going through that gate means encountering the two root questions of the journey: "Who is my self?" and "What is my work?"

In Leading from the emerging future, Scharmer and Kaufer (2013:27-43) discuss some of the most epochal events of our time, such as the fall of the Berlin wall (1989), Chernobyl, the effect of the tsunami on the Fukushima Daiichi nuclear power plant in Japan, the near meltdown of the Western financial system in 2008, and several examples from the Arab Spring. This they do to illustrate the cracks in the old system (paradigm) and the typical reaction in the liminal phase of transition. On page 29 , a remark supports the eye of the needle quotation. In all the examples of epochal events quoted, one finds, after some time:

... the rebound of the old forces as soon as the memory of the collapse began to fade away; the old forces tried to obscure the actual root causes of the breakdown in order to extend their privileged access to power and influence (an example is Wall Street's financial oligarchy).

At the moment that we reach the point of meltdown, we have a choice: We can freeze and revert to our deeply ingrained habits of the past, or we can

2009, Theory U: Leading from the Future as It Emerges, Berrett-Koehler, San Francisco. 21 Theory U is the key concept describing Scharmer's (2009) methodology. 
stop and lean into the space of the unknown, lean into that which wants to emerge.

\section{CONCLUSION}

To transform theological education will not be an easy journey. The camel is loaded with benefits and securities for those who own it, thus it will continue to rebound.

However, the cracks in the system are clearly evident for all who have eyes to see and ears to hear.

I am filled with hope and expectation about what is happening in the fresh expressions and missional shift in many mainline churches. The examples from the DRC discussed above are promising because they addressed the two questions that Scharmer and Kaufer (2013:22) asked about identity and mission. At the heart of the reformulation of their identity and mission is the kenosis principle and a realization that Philippians 2:1-18 describes the journey. However, the institutional structures in which theological education is embedded in tertiary institutions will be the eye of the needle. However, the rebound forces will be strong, which is evident in the Kenyan case study. We shall need wisdom, dialogue and "presencing" which, to my understanding, boil down to a process of theological discernment.

We need to hear the voices from the fringes. The stories from Angola, Kenya and Malawi are excellent illustrations. Similar stories exist all over Africa. I am worried that the academic theological institutions prefer to travel to the global North for conferences in big hotels, and find it difficult to embark on potholed roads less travelled. However, if we wish to follow Christ, then downward mobility will be the hallmark of a truthful journey. The church will be reborn if we are willing to be with the widows and orphans, and travel to places where we have not been before.

\section{BIBIOGRAPHY}

Algemene Sinode, 2013, Algemene Kuratoriumverslag, accessed 1 Nov 2013, from http://www.as2013.co.za/wp-content/uploads/agenda/A.15.1\%20ALGEMENE\%20 KURATORIUM.pdf

Algemene Sinode, 2013, Raamwerkdokument oor die missionale aard en roeping van die kerk, accessed 1 Nov 201, http://www.as2013.co.za/wp-content/uploads/ agenda/A.12.7\%20MISSIONALE \%20AARD \%20EN\%20ROEPING\%20VAN $\% 20$ DIE\%20NG\%20KERK.pdf 
Babbie, E. \& Mouton, J., 2010, The practice of social research, Oxford University Press, Cape Town.

Bosch, D., 1991, Transforming mission, Orbis, New York.

Brown, C. (ed.), 1975, The new international dictionary of New Testament theology, Vol. 1, Paternoster, Exeter.

Cape Town Commitment, a confession of faith and a call to action. The third Lausanne Congress, Parow-SA, AcadSA publishing.

Chifungo, D.K., 2013, An oral hermeneutics within the lay preaching context of the Nkhoma Synod of the Church of Central Africa Presbyterian (CCAP): A critical evaluation, Doctoral thesis, Stellenbosch University, from http://scholar.sun.ac.zal handle/10019.1/85597

Church of England, Report of the Mission and Public Affairs Council, 2009, Mission-shaped church: Church planting and fresh expressions of church in a changing context, Church House Publishing, London.

De Vos, A.S., Strydom, H., Fouche, C.B. \& Delport, C.S.L., 2011, Research at grass roots for social sciences and human service professions, $4^{\text {th }}$ edn., Van Schaik, Cape Town.

Ellison, P.T., 2009, 'Word-dwelling, deep listening, and faith-based moral conversation in congregations: A nested vision for learning new habits', in Keifert, P. (ed.), Testing the spirits: How theology informs the study of congregations, pp. 91-108, Eerdmans, Grand Rapids.

Gorman, M.J., 2009, Inhabitating the Cruciform God: Kenosis, justification and theosis in Paul's narrative soteriology, Eerdmans, Grand Rapids.

Guder, D.L., (ed.), 1998, Missional Church: A vision for the sending of the church in North America, Eerdmans, Grand Rapids.

Hendriks, H.J., 2004, Studying congregations in Africa, Lux-Verbi-BM, Wellington.

Hendriks, H.J., 2013a, "Contextualizing theological education in Africa by doing theology in a missional hermeneutic", in I. Phiri \& D. Werner (eds.), Handbook for Theological Education in Africa, pp. 818-831,WCC-Cluster, Genève. 
Hendriks, H.J., 2013b, "Reliable leadership, sustainable seminaries: The NetACT story 2000-2012", in I. Phiri \& D. Werner (eds.), Handbook for Theological Education in Africa, pp. 1001-1017, WCC-Cluster, Genève.

Jenkins, P., 2002, The next Christendom: The coming of global Christianity, Oxford, Oxford.

Kagema, D.N., 2008, "Leadership training for mission in the Anglican Church of Kenya", unpublished doctoral dissertation/DTh thesis?, UNISA, Pretoria.

Keifert, P. (ed.), 2009, Testing the spirits: How theology informs the study of congregations, Eerdmans, Grand Rapids.

Keifert, P., 2009, Keifert uses the same approach when addressing the challenge in his chapter, "The Bible and theological education: A report and reflections on a journey", in P. Keifert, (ed.), 2009, Testing the spirits: How theology informs the study of congregations, pp. 27-47, Eerdmans, Grand Rapids.

Kuhn, T.S., 1970, The structure of scientific revolutions, 2nd enlarged, University of Chicago, Chicago.

Meylahn, J-A., 2012, Church emerging from the cracks: A church IN, but not OF the world, SUN Press, Stellenbosch.

Msangaambe, C.E.J., 2011, Laity empowerment with regard to the missional task of the CCAP in Malawi, Doctoral thesis, Stellenbosch University, from http://scholar.sun.ac.za/handle/10019.1/6750

Munikwa, C., 2011, The Binga outreach: Contextualisation of mission in the Reformed Church in Zimbabwe, Doctoral thesis, Stellenbosch University, from http://scholar.sun.ac.za/handle/10019.1/6598

Newbigin, L., 1989, The Gospel in a pluralist society. Eerdmans, Grand Rapids.

Onwunta, U.A., 2006, Ethnicity and missional strategies within the Presbyterian Church of Nigeria, Doctoral thesis, Stellenbosch University, from http://scholar.sun.ac.za/handle/10019.1/1170

Onwunta, U.A., 2010, Ethnicity and the mission of the church in Nigeria: A Presbyterian perspective, Josany Press, Elelenwo, Port Harcourt Rivers State, Nigeria. 
Peterson, E.H., 2002, The Message: The Bible in contemporary language, NavPress, Colorado Springs, Colo.

Phiri, I. \& Werner, D. (eds.), 2013, Handbook for Theological Education in Africa, WCC-Cluster, Genève.

Ruturo, R., 2007, Lay leadership development in the Reformed Church in Zimbabwe, Doctoral thesis, Stellenbosch University, from http://hdl.handle.net/10019.1/5490.

Scharmer, C.O. \& Kaufer, K., 2013, Leading from the emerging future. From egosystem to eco-system economies, Berret-Koehler, San Francisco.

Scharmer, C.O., 2009, Theory U: leading from the future as it emerges: The social technology of presencing, Berret-Koehler, San Francisco.

Schreiter, R., Keeping alive the flame of mission in the US church, assessed 10 February 2014, from http://www.uscatholicmission.org/files/uscatholicmission/files/ articles/KEEPING\%20ALIVE\%20THE\%20FLAME\%200F\%20MISSION\%20IN\%20 THE\%20US\%20CHURCH.pdf and from http://www.maryknollaffiliates.org/midwestus/729-missionsymposiumctu.html? showall=\&limitstart=

Tickle, P., 2008, The great emergence: How Christianity is changing and why, Baker, Grand Rapids.

Tickle, P., 2012, Emergence Christianity: What it is, where it is going and why it matters, Baker, Grand Rapids.

Walls, A.F., 2002, The cross-cultural process in Christian history, Orbis, Maryknoll, NY.

Wright, N.T., 1991, The climax of the covenant: Christ and the law in Pauline theology, Fortress Minneapolis.

\section{KEY WORDS}

Theological education in Africa

Kenosis - power

Kinkuni Angola

CCAP Malawi

Anglican Church of Kenya

Fresh expressions

Third wave missions 